\title{
Pengaruh Tax Avoidance Terhadap Nilai Perusahaan Studi Pada Perusahaan Manufaktur yang Terdaftar Di BEI
}

\author{
Sri Yuliandana, Junaidi, Abid Ramadhan \\ Universitas Muhammadiyah Palopo \\ E-Mail: syuliandana35@gmail.com
}

\begin{abstract}
This study is a quantitative study that aims to the effect of tax avoidance on firm value in manufacturing companies listed on the Indonesia Stock Exchange for the 2014-2018 period. The population in this study were manufacturing companies listed and listed on the Indonesia Stock Exchange for the 2014-2018 period, totaling 117 companies. The sampling technique in this study was purposive sampling, in order to obtain 25 sample companies. The method used in analyzing the effect of independent variables on the dependent in this study is panel data regression analysis using Eviews 10 software. The results show that tax avoidance has a negative and insignificant effect on firm value. This shows that the higher the tax avoidance done by the company, the lower the firm value. The limitation in this study is that it does not include elements of other variables outside of tax avoidance which may affect firm value.
\end{abstract}

Keywords: tax avoidance, firm value, indonesia stock exchange

\begin{abstract}
ABSTRAK
Penelitian ini merupakan penelitian kuantitatif yang bertujuan untuk mengetahui pengaruh penghindaran pajak terhadap nilai perusahaan pada perusahaan manufaktur yang terdaftar di Bursa Efek Indonesia periode 2014-2018. Populasi dalam penelitian ini adalah perusahaan manufaktur yang terdaftar dan terdaftar di Bursa Efek Indonesia periode 2014-2018 yang berjumlah 117 perusahaan. Teknik pengambilan sampel dalam penelitian ini adalah purposive sampling, sehingga diperoleh 25 perusahaan sampel. Metode yang digunakan dalam menganalisis pengaruh variabel independen terhadap dependen dalam penelitian ini adalah analisis regresi data panel dengan menggunakan software Eviews 10. Hasil penelitian menunjukkan bahwa penghindaran pajak berpengaruh negatif dan tidak signifikan terhadap nilai perusahaan. Hal ini menunjukkan bahwa semakin tinggi penghindaran pajak yang dilakukan oleh perusahaan maka semakin rendah nilai perusahaan. Batasan dalam penelitian ini adalah tidak memasukkan unsur variabel lain di luar penghindaran pajak yang dapat mempengaruhi nilai perusahaan.
\end{abstract}

Kata Kunci: penghindaran pajak, nilai perusahaan, bursa efek indonesia

\section{PENDAHULUAN}

Perusahaan pada umumnya bertujuan untuk meningkatkan nilai perusahaan setiap periodenya. Deriyarso (2014) menyatakan bahwa peningkatan nilai perusahaan yang tinggi merupakan tujuan jangka panjang yang seharusnya dicapai bagi perusahaan yang sudah terbuka (go public). Tujuan meningkatkan nilai perusahaan merupakan tolak ukur keberhasilan suatu perusahaan dalam mencapai laba yang direncanakan serta dapat meningkatkan kemakmuran pemilik perusahaan. Nilai perusahaan mencerminkan nilai dari pendapatan yang diinginkan dimasa yang akan datang dan indikator bagi pasar dalam menilai perusahaan secara keseluruhan (Manopo dan Arie, 2016). Hal ini

\section{JIAKES}

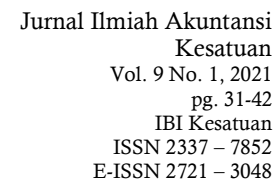


Companies

Value and Tax

Avoidance

$\underline{32}$

memberi dampak para pemegang saham tetap mempertahankan sahamnya dan menarik calon investor untuk menanamkan modalnya ke perusahaan tersebut.

Berbagai cara dilakukan oleh pihak manajemen untuk mongoptimalkan laba perusahaan dan memaksimalkan nilai perusahaan. Salah satu cara manajemen dalam memaksimalkan nilai perusahaan yaitu dengan menyesuaikan biaya pajak yang dibayarkan oleh perusahaan. Bagi Negara pajak merupakan sumber pendanaan bagi penyelenggaraan pemerintahan, dan bagi perusahaan perpajakan merupakan beban yang akan mengurangi keuntungan perusahaan. Hal ini berdampak pada perusahaan yang berupaya mendapatkan pengurangan beban pajak yang dibayarkan baik secara legal maupun ilegal. Perencanaan pajak dapat digunakan untuk mengatur pengeluaran pajak yang bertujuan untuk mengurangi beban pajak.

Perencanaan pajak atau tax planning merupakan salah satu cara yang dilakukan oleh manajemen untuk mengurangi jumlah pajak yang dibayarkan oleh perusahaan. Salah satu strategi dalam perencanaan pajak yaitu dengan melakukan penghindaran pajak (tax avoidance). Penghindaran pajak adalah upaya perusahaan untuk menekan rendah pajak yang dibayarkan dengan melakukan praktik secara legal dan tidak bertentangan dengan ketentuan perpajakan (Adityamurti dan Ghozali, 2017).

Segala bentuk kegiatan tax avoidance dapat memberikan pengaruh terhadap wajib pajak, baik kegiatan yang dilegalkan oleh pajak seperti melakukan manajemen pajak dan atau kegiatan ilegal seperti penggelapan pajak untuk mengurangi beban pajak. Selain memberikan keuntungan bagi perusahaan, tax avoidance juga dapat memberikan dampak negatif bagi perusahaan. Tax avoidance tidaklah gratis terdapat biaya langsung meliputi biaya pelaksanaan, kehilangan reputasi dan adanya potensi hukuman tertentu (Chen et al, 2013). Hal ini disebabkan karena tax avoidance dapat mencerminkan adanya kepentingan pribadi oleh manajer dalam memanipulasi laba perusahaan yang mengakibatkan adanya informasi yang tidak benar bagi investor. Hal ini akan berdampak kepada para investor yang memberikan penilaian rendah bagi perusahaan.

Di dunia ini kasus penghindaran pajak merupakan kasus umum yang terjadi di berbagai negara. Bahkan khusus di Indonesia sendiri penghindaran pajak cukup banyak terjadi pada perusahaan-perusahaan dengan modus yang beragam, seperti kasus pada perusahaan PT Garuda Metalindo yang dalam neraca perusahaannya menunjukkan bahwa total utang (bank dan lembaga keuangan) mengalami peningkatan. Dalam laporan keuangan per Juni 2016, nilai utang bank jangka pendek mencapai Rp200 miliar, meningkat dari akhir Desember 2015 yang hanya berjumlah Rp48 miliar. Emiten yang ditetapkan sebagai saham BOLT ini menggunakan modal yang diperoleh dari pinjaman atau hutang untuk menghindari pembayaran pajak yang harus dikeluarkan perusahaan. Perusahaan yang menggunakan pembiayaan hutang akan menanggung beban bunga yang harus dibayar, semakin besar hutang maka semakin besar pula biaya bunga yang akan ditanggung perusahaan. Beban bunga yang tinggi akan mengurangi beban pajak (www.finance.detik.com, 20 November 2019).

Perusahaan di atas melakukan penghindaran pajak dalam batas wajar tanpa melanggar hukum pajak di suatu Negara, hal ini dilakukan perusahaan dengan tujuan yang sama yaitu untuk mendapatkan laba secara maksimal dengan meminimalkan pajak yang ditanggung sehingga dapat meningkatkan harga saham perusahaan dengan cara yang berbeda-beda. Hal tersebut dapat dilihat ketika harga saham naik maka nilai perusahaannya menjadi optimal.

Penelitian terdahulu yang terkait dengan penelitian ini telah bayak dilakukan oleh beberapa peneliti. Penelitian sebelumnya yang dilakukan oleh Victory dan Cheisviyani (2016) menyatakan bahwa tax avoidance berpengaruh positif signifikan terhadap nilai perusahaan. Penelitian yang sama dilakukan oleh Kurniawan dan Syafruddin (2017) menyatakan bahwa perilaku penghindaran pajak berpengaruh positif signifikan terhadap nilai perus ahaan. Begitu juga dengan penelitian yang dilakukan oleh Apsari dan Setiawan (2018) menyatakan bahwa ETR berpengaruh positif terhadap nilai 
perusahaan, nilai ETR yang rendah mengindikasikan tax avoidance yang tinggi berpengaruh terhadap menurunnya nilai perusahaan.

Terdapat hasil yang bertolak belakang dengan penelitian sebelumnya yaitu penelitian yang dilakukan oleh Ilmiani dan Sutrisno (2014) menyatakan bahwa tax avoidance berpengaruh signifikan negatif terhadap nilai perusahaan. Begitu juga dengan penelitian yang dilakukan oleh Wardani dan Juliani (2018) yang menyatakan bahwa tax avoidance berpengaruh signifikan negatif terhadap nilai perusahaan. Penelitian yang sama juga dilakukan oleh Fadillah (2018) menyatakan bahwa tax avoidance berpengaruh negatif terhadap nilai perusahaan.

\section{METODE PENELITIAN}

Populasi dalam penelitian ini adalah seluruh emiten atau perusahaan manufaktur yang terdaftar di Bursa Efek Indonesia (BEI) periode tahun 2014 sampai dengan 2018. Perusahaan yang menjadi populasi dalam penelitian ini sebanyak 117 perusahaan. Pengambilan sampel dalam penelitian ini dilakukan dengan menggunakan metode purposive sampling. Menurut Sugiyono (2013) metode purposive sampling adalah teknik penentuan sampel dengan pertimbangan tertentu. Kriteria dalam penelitian ini untuk mendapatkan sampel adalah dengan melihat poin-poin sebagai beriku:

1. Perusahaan manufaktur yang terdaftar di BEI periode tahun 2014 hingga 2018,

2. Perusahaan mengeluarkan atau menerbitkan annual report dan financial statements selama periode observasi dari tahun 2014 sampai dengan 2018,

3. Perusahaan yang pendapatan sebelum pajaknya selalu positif dari tahun 2014 hingga 2018,

4. Laporan keuangan disajikan dalam mata uang Rupiah,

5. Perusahaan menerbitkan laporan keuangan per tanggal 31 Desember.

\section{Operasional Variabel}

Tax Avoidance. Penghindaran pajak (tax avoidance) merupakan upaya yang dilakukan oleh perusahaan untuk meminimalkan beban pajaknya. Tindakan tax avoidance dilakukan dengan mencari celah-celah yang ada dalam peraturan perundang-undangan. Pengukuran tax avoidance menggunakan Cash_ETR yaitu dengan membagi kas yang dikeluarkan untuk biaya pajak dibagi dengan laba sebelum pajak.

Keterangan:

$$
\text { CETR }=\frac{\text { Pembayaran Pajak }}{\text { Laba Sebelum Pajak }}
$$

Cash_ETR = Cash Effective Tax Rates sebagai indicator tax avoidance

Cash Tax Paid = Beban pajak yang dibayar oleh perusahaan

Earning Before Tax = Laba perusahaan sebelum pajak

Tax Avoidance dalam penelitian ini diukur dengan menggunakan skala nominal, yaitu 1 melakukan penghindaran pajak dan 0 tidak melakukan pengindaran pajak. Menurut Budiman dan Setiyono (2012) perusahaan dikategorikan melakukan penghindaran pajak apabila Cash Effective Tax Rate (CETR) kurang dari 25\%, dan apabila Cas Effective Tax Rate (CETR) lebih dari 25\% dikategorikan tidak melakukan penghindaran pajak.

Nilai perusahaan merupakan pandangan investor terhadap perusahaan yang dilihat melalui harga sahamnya. Pengukuran nilai perusahaan pada penelitian ini menggunakan rumus Tobin's $\mathrm{Q}$. Tobin's $\mathrm{Q}$ adalah salah satu alat ukur atau rasio yang mendefenisikan nilai perusahaan sebagai bentuk dari gabungan nilai antara aset berwujud dan aset tidak berwujud. Tobin's $Q$ yang diukur dengan rumus berikut:

Keterangan :

$$
\mathbf{Q}=\frac{(E M V+D)}{(E B V+D)}
$$

$\mathrm{Q} \quad=$ nilai perusahaan

$\mathrm{EMV}=$ nilai pasar ekuitas

EBV = nilai buku dari total aktiva

$\mathrm{D} \quad=$ nilai buku dari total hutang

Companies' Value and Tax Avoidance Order 
Companies

Value and Tax

Avoidance

34

Nilai perusahaan dinilai berdasarkan rasio Tobin's $Q$ pada tanggal 31 Desember untuk melihat reaksi penghindaran pajak diakhir periode pengamatan. Nilai perusahaan dalam penelitian ini diukur dengan skala nominal berkisar antara 0 dan 1 . Jika nilai rasio Tobin's Q lebih besar dari 1, maka itu menunjukkan bahwa pasar menetapkan harapan yang tinggi terhadap perusahaan itu dan hal ini bisa menarik kepercayaan pasar terhadap perusahaan tersebut. Namun jika sebaliknya, nilai rasio Tobin's Q dari perusahaan lebih kecil dari 1, hal ini mengindikasikan bahwa perusahaan tidak sanggup atau tidak mampu membuat nilai pasar maksimal. Dengan kata lain, apabila nilai Tobin's $Q$ lebih besar dari 1, maka saham perusahaan dianggap meningkat sangat tinggi. Sebaliknya apabila nilai Tobin's Q suatu perusahaan lebih kecil dari 1, maka saham perusahaan tersebut dianggap semakin rendah atau menurun.

Analisis Data

Metode analisis data yang akan digunakan untuk menguji model dalam penelitian ini adalah analisis deskriptif, analisis verifikatif, uji asumsi klasik, analisis regresi dan uji hipotesis. Analisis verifikatif dalam penelitian ini menggunakan analisis regresi data panel (pooled data). Penelitian ini menggunakan data dari perusahaan manufaktur yang terdaftar di BEI selama 5 tahun. Untuk menentukan model yang paling tepat digunakan dalam regresi panel maka harus dilakukan pemilihan model dengan uji chow, uji hausman dan uji lagrange multiplier (Ali, 2016). Alat pengolahan data dalam penelitian ini menggunakan software Microsoft excel, SPSS 24 dan Eviews 10.

HASIL DAN PEMBAHASAN

Uji Statistik Deskriptif

Tabel 1 Statistik Deskriftif

\begin{tabular}{|l|r|r|r|r|r|}
\hline Variables & $\mathrm{N}$ & \multicolumn{1}{c|}{ Minimum } & \multicolumn{1}{c|}{ Maximum } & \multicolumn{1}{c|}{ Mean } & \multicolumn{1}{c|}{ Std. Deviation } \\
\hline Tax Avoidance & 125 &, 03 &, 77 &, 2707 &, 11309 \\
\hline Nilai Perusahaan & 125 &,- 47 & 3,04 &, 8676 &, 83841 \\
\hline Valid N (listwise) & 125 & & & & \\
\hline
\end{tabular}

Sumber: Data Primer Diolah

Hasil akhir dari pemilihan sampel penelitian ini diperoleh 25 perusahaan dengan kelengkapan datanya yang kemudian menjadi 125 perusahaan selama 5 tahun penelitian. Data yang ditemukan oleh penulis kemudian diolah untuk mengetahui nilai setiap variabel penelitian. Data yang diolah disajikan dalam bentuk statistik deskriptif yang dapat dilihat pada tabel 1 . Berdasarkan hasil uji statistik deskriptif pada tabel 1 diketahui bahwa variabel independen yaitu tax avoidance yang diproksikan dengan Cash_ETR menunjukkan nilai minimum 0,03 dan nilai maksimum 0,77 sedangkan nilai rata-rata sebesar 0,2707 dengan standar deviasi 0,11309. Hasil statistik deskriptif terhadap variabel dependen yaitu nilai perusahaan yang diproksikan dengan Tobin's $\mathrm{Q}$ menunjukkan nilai minimum $-0,47$ dan nilai maksimum 3,04 sedangkan nilai rata-rata sebesar 0,8676 dengan standar deviasi 0,83841. Seperti yang diketahui bahwa hasil statistik deskriptif di atas menghasilkan nilai rata-rata yang lebih besar dibandingkan nilai standar deviasinya dari seluruh variabel yang dimiliki. Hal ini mengidentifikasikan bahwa standar error dari variabel tersebut rendah karena dilihat dari kualitas data yang cukup baik memiliki nilai rata-rata yang lebih besar dari nilai standar deviasinya.

\section{Uji Analisis Model Regresi Data Panel}

Model regresi data panel ( $p o o l$ ) yaitu data yang merupakan gabungan antara data runtun waktu (time series) dengan data seksi silang (cross section). Agar data panel memperoleh hasil yang sesuai dan menghasilkan yang terbaik, maka beberapa metode dapat digunakan untuk mengestimasi model regresi dengan menggunakan data panel. Teknik estimasi model regresi data panel membahas tiga metode yang bisa digunakan yaitu: memilih antara Common Effect Model, Fixed Effect Model dan Random Effect Model (Basuki dan Prawoto, 2017:276).

Pendekatan Common Effect 
Pendekatan Common Effect (OLS) tidak memperhatikan dimensi individu maupun waktu sehingga diestimasikan perilaku data perusahaan sama dalam beberapa kurun waktu (Basuki dan Prawoto, 2017).

Tabel 2 Uji Common Effect (OLS)

\begin{tabular}{|l|l|l|l|l|}
\hline & Coefficient & Std. Error & t-Statistic & Prob. \\
\hline Cash_ETR & $-1,03079$ & 0,698155 & $-1,476448$ & 0,1424 \\
\hline
\end{tabular}

Seperti yang dapat dilihat pada output diatas tabel 2 nilai koefisien Cash_ETR sebesar 1,03079 dimana nilai koefisien ini digunakan untuk membentuk persamaan regresi data panel. Selain itu nilai prob Cash_ETR yang didapat sebesar 0,1424 yang berarti Cash_ETR lebih besar dari 0,05 maka Ho ditolak dan $\mathrm{H} a$ diterima.

Pendekatan Fixed Effect. pendekatan ini didasarkan pada intersepsi yang berbeda antar perusahaan, tetapi intersepsi itu sama dalam waktu (time in variant). Selain itu, model ini juga mengasumsikan bahwa koefisien regresi (Slope) tetap antar perusahaan dan antar waktu (Basuki dan Prawoto, 2017).

Tabel 3 Uji Fixed Effect (OLS)

\begin{tabular}{|l|l|l|l|l|}
\hline & Coefficient & Std. Error & t-Statistic & Prob. \\
\hline Cash_ETR & $-0,555686$ & 0,685607 & $-0,810502$ & 0,4196 \\
\hline
\end{tabular}

Seperti yang dapat dilihat pada output diatas tabel 3 nilai koefisien Cash_ETR sebesar 0,555686 dimana nilai koefisien ini digunakan untuk membentuk persamaan regresi data panel. Selain itu nilai prob Cash_ETR yang didapat sebesar 0,4196 yang berarti Cash_ETR lebih besar dari 0,05 maka Ho ditolak dan $\mathrm{H} a$ diterima.

Pendekatan Random Effect. Pendekatan ini mengestimasi data panel dengan asumsi koefisien slope konstan dan intersep berbeda antara individu dan antar waktu (Random Effect) Basuki dan Prawoto (2017).

Tabel 4 Uji Random Effect (OLS)

\begin{tabular}{|l|l|l|l|l|}
\hline & Coefficient & Std. Error & t-Statistic & Prob. \\
\hline Cash_ETR & $-0,719091$ & 0,646473 & $-1,112329$ & 0,2682 \\
\hline
\end{tabular}

Seperti yang dapat dilihat pada output diatas tabel 4 nilai koefisien Cash_ETR sebesar 0,719091 dimana nilai koefisien ini digunakan untuk membentuk persamaan regresi data panel. Selain itu nilai prob Cash_ETR yang didapat sebesar 0,2682 yang berarti Cash_ETR lebih besar dari 0,05 maka Ho ditolak dan Ha diterima.

\section{Uji Pemilihan Model}

Setelah data mentah diolah menjadi rasio keuangan dan variabelnya telah ditentukan, langkah selanjutnya adalah memilih model penelitian yang paling sesuai diantara common effect (CE), fixed effect ( $\mathrm{FE})$ dan random effect $(\mathrm{RE})$.

Uji Chow digunakan untuk menentukan model yang paling sesuai antara fixed effect dan common effect (Ali, 2016). Pengambilan keputusan dengan melihat nilai probabilitas (p) untuk Cross-Section F. Jika nilai $\mathrm{p}>0,05$ maka model yang terpilih adalah Common Effect Model. Tetapi jika $\mathrm{p}<0,05$ maka model yang dipilih adalah Fixed Effect Model.

Tabel 5 Uji Chow

\begin{tabular}{|c|c|c|c|}
\hline Effects Test & Statistic & d.f. & Prob. \\
\hline Cross-section F & 3,718399 & $(24,99)$ & 0,0000 \\
\hline Cross-section Chi-square & 80,325789 & 24 & 0,0000 \\
\hline
\end{tabular}

Berdasarkan uji Chow di atas Tabel 5, kedua nilai probabilitas Cross Section F dan Chi square lebih kecil dari Alpha 0,05 sehingga Ho ditolak. Oleh karena itu, model yang paling baik untuk digunakan adalah yang menggunakan metode fixed effect. Berdasarkan hasil uji Chow yang menolak hipotesis nol, pengujian data akan dilanjutkan dengan uji Hausman.

Uji Hausman dilakukan untuk membandingkan atau memilih mana model yang terbaik antara Fixed Effect Model dan Random Effect Model. Pengambilan keputusan
Companies'Value and Tax Avoidance Order

\section{政}


Companies

Value and Tax

Avoidance

$\underline{36}$ dengan melihat nilai probabilitas (p) untuk Cross-Section Random. Jika nilai $\mathrm{p}>0,05$ maka model yang terpilih adalah Random Effect Model. Tetapi jika $\mathrm{p}<0,05$ maka model yang dipilih adalah Random Effect Model.

Tabel 6 Uji Hausman

\begin{tabular}{|l|c|r|rr|}
\hline Test Summary & Chi-Sq. Statistic & Chi-Sq. d.f. & Prob. \\
\hline Cross-section random & 0,512205 & & \multicolumn{2}{|l|}{0,4742} \\
\hline
\end{tabular}

Nilai Chi Square Statistics pada Cross-section Random sebesar 0,512205 dengan nilai $\mathrm{p}=$ $0,4742>0,05$, sehingga menolak $\mathrm{H} a$. Jadi berdasarkan uji hausman, model yang terbaik digunakan adalah model dengan menggunakan metode Random Effect Model.

\section{Uji Asumsi Klasik}

Uji asumsi klasik bertujuan untuk mengidentifikasi dan menguji kelayakan model regresi yang digunakan dalam penelitian ini. Di bawah ini adalah pengujian asumsi klasik yang digunakan dalam penelitian ini.

Uji normalitas digunakan untuk menguji apakah nilai residual dalam model regresi berdistribusi normal. Model regresi yang baik adalah model dengan nilai residu yang berdistribusi normal. Kriteria dalam mengambil keputusan adalah dengan melihat nilai probability Jarque-Bera yang lebih besar dari 0,05 yang berarti data berdistribusi normal.

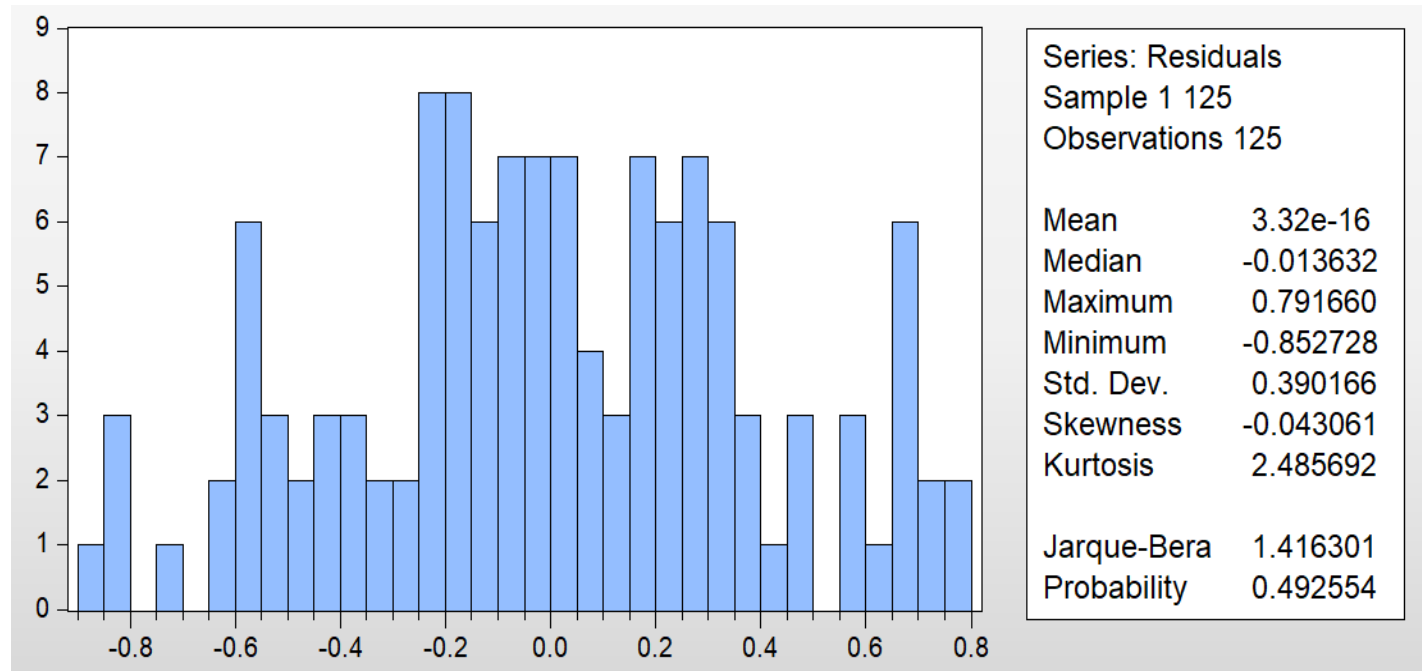

Gambar 1 Grafik Histogram

Uji normalitas berdasarkan nilai probability Jarque Berra (JB) sebesar 0,492 > 0,05 maka data dapat dikatakan data dalam penelitian ini berdistribusi Normal.

Uji heterokedastisitas dilakukan untuk menguji apakah dalam model regresi terjadi ketidaksamaan varian dari residual satu pengamatan ke pengamatan lain (Ghozali, 2013). Ada beberapa cara untuk menguji apakah model regresi yang kita gunakan lolos dari heteroskedastisitas. Dalam penelitian ini, uji Glejser digunakan untuk mendeteksi ada atau tidaknya masalah heteroskedastisitas, yang melakukan regresi nilai absolut dengan variabel bebas. Uji Glejser dapat ditentukan dari probabilitas nilai absolut residual. Jika nilai probabilitas $>0,05$ maka tidak terjadi heteroskedastisitas, namun jika nilai probabilitas $<0,05$ maka terjadi heteroskedastisitas (Ali, 2016). Berdasarkan hasil uji Glejser dapat diketahui nilai signifikan dari variabel bebas invrsquare_Cash_ETR memiliki nilai probabilitas $0,6643>$ dari 0,05 . Dengan demikian dapat disimpulkan bahwa tidak mengandung heteroskedastisitas.

Uji autokorelasi dirancang untuk menguji apakah terdapat korelasi antara kesalahan pengganggu selama periode $\mathrm{t}$ dan $\mathrm{t}-1$. Uji Durbin Watson dapat digunakan untuk mendeteksi ada atau tidaknya autokorelasi dalam model (Ali, 2016). Dari tabel 8 diatas dapat dilihat bahwa nilai $\mathrm{Obs}^{*} \mathrm{R}$-Squared sebesar 0,043018 $>0,05$, dengan demikian hasil dari uji LM Test tidak mengindikasikan terjadinya autokorelasi. 
Tabel 7 Uji Heteroskedastisitas

Heteroskedasticity Test: Glejser

Null hypothesis: Homoskedasticity

\begin{tabular}{llll}
\hline \hline F-statistic & 0.189305 & Prob. F(1,123) & 0.6643 \\
Obs*R-squared & 0.192088 & Prob. Chi-Square(1) & 0.6612 \\
Scaled explained SS & 0.498034 & Prob. Chi-Square(1) & 0.4804 \\
\hline \hline
\end{tabular}

Test Equation:

Dependent Variable: ARESID

Method: Least Squares

Date: 09/03/20 Time: 16:22

Sample: 1125

Included observations: 125

\begin{tabular}{lrrrr}
\hline \hline \multicolumn{1}{c}{ Variable } & Coefficient & Std. Error & t-Statistic & Prob. \\
\hline \hline \multirow{2}{*}{ C } & 160.3654 & 68.16650 & 2.352554 & 0.0202 \\
INVRSQUARE_CASH_ETR & -0.215284 & 0.494801 & -0.435092 & 0.6643 \\
\hline \hline R-squared & 0.001537 & Mean dependent var & 150.6419 \\
Adjusted R-squared & -0.006581 & S.D. dependent var & 717.6459 \\
S.E. of regression & 720.0034 & Akaike info criterion & 16.01226 \\
Sum squared resid & 63763802 & Schwarz criterion & 16.05751 \\
Log likelihood & -998.7662 & Hannan-Quinn criter. & 16.03064 \\
F-statistic & 0.189305 & Durbin-Watson stat & 2.018107 \\
Prob(F-statistic) & 0.664258 & & \\
\hline \hline
\end{tabular}

Tabel 8 Uji Autokorelasi

Breusch-Godfrey Serial Correlation LM Test

Null hypothesis: No serial correlation at up to 2 lags

\begin{tabular}{llll}
\hline \hline F-statistic & 0.020828 & Prob. F(2,121) & 0.9794 \\
Obs*R-squared & 0.043018 & Prob. Chi-Square(2) & 0.9787 \\
\hline
\end{tabular}

Test Equation:

Dependent Variable: RESID

Method: Least Squares

Date: 09/03/20 Time: 16:21

Sample: 1125

Included observations: 125

Presample missing value lagged residuals set to zero.

\begin{tabular}{lrrrr}
\hline \multicolumn{1}{c}{ Variable } & Coefficient & Std. Error & t-Statistic & Prob. \\
\hline \hline C & 0.078757 & 70.28104 & 0.001121 & 0.9991 \\
INVRSQUARE_CASH_ETR & -0.001191 & 0.510236 & -0.002335 & 0.9981 \\
RESID(-1) & -0.014040 & 0.090923 & -0.154412 & 0.8775 \\
RESID(-2) & -0.012327 & 0.090913 & -0.135593 & 0.8924 \\
\hline \hline R-squared & 0.000344 & Mean dependent var & $2.91 \mathrm{E}-14$ \\
Adjusted R-squared & -0.024441 & S.D. dependent var & 733.4110 \\
S.E. of regression & 742.3194 & Akaike info criterion & 16.08891 \\
Sum squared resid & 66675609 & Schwarz criterion & 16.17942 \\
Log likelihood & -1001.557 & Hannan-Quinn criter. & 16.12568 \\
F-statistic & 0.013885 & Durbin-Watson stat & 2.000253 \\
Prob(F-statistic) & 0.997754 & & \\
\hline \hline
\end{tabular}

Uji linearitas dilakukan untuk mengetahui model yang dibuktikan memiliki model linear atau tidak. Dalam melihat linear atau tidaknya pada penelitian ini menggunakan Ramsey Reset Test yakni uji kombinasi non-linear dari nilai yang dihasilkan untuk membantu menjelaskan variabel independen. Uji Ramsey Reset Test dilihat dari nilai $\mathrm{p}$ value yang ditunjukkan pada kolom probability baris $F$-statistics dari nilai probabilitas $\mathrm{F}$ hitung yang lebih besar dari 0,05 maka model regresi memenuhi asumsi linearitas dan sebaliknya. Nilai probabilitas $\mathrm{F}$ hitung dapat dilihat pada baris $\mathrm{F}$ statistik kolom probability.

Dari tabel 9 dapat dilihat bahwa nilai probability sebesar $0,7198>0,05$, sehingga dapat disimpulkan bahwa model regresi memenuhi asumsi linearitas.

Analisis Regresi Data Panel

Analisis regresi linear data panel pada penelitian ini menggunakan metode Random Effect. Pemilihan metode Random Effects sebagai metode analisis data panel pada 
Companies

Value and Tax

Avoidance penelitian ini sebelumnya telah diuji melalui uji chow dan uji hausman terlebih dahulu, sehingga akhirnya metode Random Effect yang paling tepat untuk menguji data panel pada penelitian ini.

Tabel 9 Uji Linearitas

Ramsey RESET Test

Equation: UNTITLED

Specification: INVRSQUARE TOBINS Q C INVRSQUARE CASH_ETR

Omitted Variables: Squares of fitted values

\begin{tabular}{|c|c|c|c|}
\hline & Value & df & Probability \\
\hline t-statistic & 0.359613 & 122 & 0.7198 \\
\hline F-statistic & 0.129321 & $(1,122)$ & 0.7198 \\
\hline Likelihood ratio & 0.132431 & 1 & 0.7159 \\
\hline \multicolumn{4}{|l|}{ F-test summary: } \\
\hline & Sum of Sq. & df & Mean Squares \\
\hline Test SSR & 70626.36 & 1 & 70626.36 \\
\hline Restricted SSR & 66698562 & 123 & 542264.7 \\
\hline Unrestricted SSR & 66627936 & 122 & 546130.6 \\
\hline \multicolumn{4}{|l|}{ LR test summary: } \\
\hline & Value & & \\
\hline Restricted LogL & -1001.579 & & \\
\hline Unrestricted LogL & -1001.512 & & \\
\hline
\end{tabular}

Tabel 10 Hasil Uji Regresi Data Panel dengan Metode Random Effect

\begin{tabular}{|c|c|c|c|c|}
\hline \multicolumn{5}{|c|}{ Dependent Variable: TOBINS_Q } \\
\hline \multicolumn{5}{|c|}{ Method: Panel EGLS (Cross-section random effects) } \\
\hline \multicolumn{5}{|c|}{ Date: $09 / 07 / 20 \quad$ Time: $22: 22$} \\
\hline \multicolumn{5}{|c|}{ Sample: 20142018} \\
\hline \multicolumn{5}{|c|}{ Periods included: 5} \\
\hline \multicolumn{5}{|c|}{ Cross-sections included: 25} \\
\hline \multicolumn{5}{|c|}{ Total panel (balanced) observations: 125} \\
\hline \multicolumn{5}{|c|}{ Swamy and Arora estimator of component variances } \\
\hline Variable & Coefficient & Std. Error & t-Statistic & Prob. \\
\hline $\mathrm{C}$ & 1,062387 & 0,214671 & 4,948916 & 0 \\
\hline CASH_ETR & $-0,719091$ & 0,646473 & $-1,112329$ & 0,2682 \\
\hline
\end{tabular}

Persamaan regresinya sebagai berikut:

Tobin's $\mathrm{Q}=\alpha+\beta^{*}$ Cash_ETR + et $\quad$ Tobin's $Q=1,062387-0,719091+$ et

Dimana:

Tobin's $\mathrm{Q} \quad=$ Rasio dari nilai perusahaan

$\alpha \quad=$ Konstanta

$\beta \quad=$ Koefisien regresi

CTER = Tarif pajak efektif sebagai proksi penghindaran pajak (tax avoidance)

et $\quad=$ Disturbance error

Dari hasil persamaan diatas dapat diketahui bahwa nilai konstanta sebesar 1,062387 yang berarti bahwa nilai konsistensi variabel nilai perusahaan sebesar 1,062387. Koefisien regresi tax avoidance sebesar - 0,719091 yang menyatakan bahwa pengurangan $1 \%$ tax avoidance maka nilai perusahaan akan berkurang sebesar 0,719091 . Koefisien regresi tersebut negatif, sehingga dapat dikatakan bahwa arah pengaruh tax avoidance $(\mathrm{X})$ terhadap nilai perusahaan $(\mathrm{Y})$ adalah negatif. Berdasarkan nilai probabilitas dari tabel diatas sebesar $0,2682>0,05$ sehingga dapat disimpulkan bahwa variabel tax avoidance (X) berpengaruh negatif dengan tingkat probabilitas 5 persen terhadap nilai perusahaan $(\mathrm{Y})$.

\section{Koefisien Determinasi $\left(R_{2}\right)$}

Analisis determinasi adalah ukuran yang menunjukkan seberapa besar variabel $\mathrm{X}$ memberikan kontribusi terhadap variable Y. Analisis determinasi digunakan untuk mengetahui persentase sumbangan pengaruh variable independen secara serentak terhadap variable dependen. Dari tabel 11 dapat diketahui bahwa nilai koefisien determinasi $\left(\mathrm{R}^{2}\right)$ sebesar 0,009998. Hal ini menunjukkan bahwa variabel tax avoidance 
tidak berpengaruh atau tidak mampu menjelaskan variasi variabel nilai perusahaan sebesar $1 \%$ dan sisanya dipengaruhi faktor lain yang tidak diteliti dalam penelitian in.

Tabel 11 Hasil Uji Hipotesis dengan Metode Random Effect

\begin{tabular}{|c|c|c|c|c|}
\hline \multicolumn{5}{|c|}{ Dependent Variable: TOBINS_Q } \\
\hline \multicolumn{5}{|c|}{ Method: Panel EGLS (Cross-section random effects) } \\
\hline \multicolumn{5}{|c|}{ Date: $09 / 07 / 20 \quad$ Time: $22: 22$} \\
\hline \multicolumn{5}{|c|}{ Sample: 20142018} \\
\hline \multicolumn{5}{|l|}{ Periods included: 5} \\
\hline \multicolumn{5}{|c|}{ Cross-sections included: 25} \\
\hline \multicolumn{5}{|c|}{ Total panel (balanced) observations: 125} \\
\hline \multicolumn{5}{|c|}{ Swamy and Arora estimator of component variances } \\
\hline Variable & Coefficient & Std. Error & $t$-Statistic & Prob. \\
\hline $\mathrm{C}$ & 1,062387 & 0,214671 & 4,948916 & 0 \\
\hline CASH_ETR & $-0,719091$ & 0,646473 & $-1,112329$ & 0,2682 \\
\hline \multicolumn{5}{|c|}{ Weighted Statistics } \\
\hline$R$-squared & 0,009998 & Mean dependent var & & 0,444175 \\
\hline Adjusted $R$-squared & 0,001949 & S.D. dependent var & & 0,710002 \\
\hline S.E. of regression & 0,70931 & Sum squared resid & & 61,88383 \\
\hline F-statistic & 1,242202 & Durbin-Watson stat & & 1,641743 \\
\hline Prob(F-statistic) & 0,26722 & & & \\
\hline \multicolumn{5}{|c|}{ Unweighted Statistics } \\
\hline$R$-squared & 0,015822 & Mean dependent var & & 0,8676 \\
\hline Sum squared resid & 95,2394 & Durbin-Watson stat & & 1,145844 \\
\hline
\end{tabular}

\section{Uji Hipotesis}

Uji t dalam penelitian ini digunakan untuk mengetahui apakah model regresi variabel independen secara parsial atau individual berpengaruh signifikan terhadap variabel dependen.

Hipotesis:

Ho : Tax avoidance tidak berpengaruh secara signifikan terhadap nilai perusahaan

$\mathrm{H} a \quad$ : Tax avoidance berpengaruh secara signifikan terhadap nilai perusahaan

Berdasarkan tabel 11 diperoleh hasil estimasi variabel tax avoidance memiliki nilai probabilitas sebesar 0,2682 dengan koefisien -0,719091. Nilai tersebut menunjukkan bahwa tax avoidance berpengaruh negatif dan tidak signifikan terhadap nilai perusahaan. Berdasarkan hipotesis yang diajukan menerima Ho (menolak $\mathrm{H} a$ ) yang artinya secara statistik tax avoidance berpengaruh negatif dan tidak signifikan terhadap nilai perusahaan.

\section{Pembahasan Hasil Penelitian}

Pengaruh Tax Avoidance Terhadap Nilai Perusahaan. Berdasarkan hasil uji statistik t variabel tax avoidance memiliki tingkat signifikansi 0,2682 dengan nilai signifikansi 0,05. Hal ini menunjukkan bahwa variabel tax avoidance berpengaruh secara tidak signifikan terhadap variabel dependen yakni nilai perusahaan karena tingkat signifikansi variabel tax avoidance berada diatas nilai signifikan 0,05. Nilai koefisien sebesar -0,719091 menunjukkan bahwa semakin tinggi aktivitas tax avoidance yang dilakukan oleh perusahaan akan berdampak pada berkurangnya nilai perusahaan. Ini menandakan bahwa hipotesi nol diterima dan hipotesis alternatif ditolak. Dari hasil penelitian tersebut hal ini juga sejalan dengan teori keagenan, dimana jika dari pihak manajer perusahaan ketika ingin melakukan tax avoidance berdasarkan monitoring dari instirusi maka dapat meningkatkan nilai perusahaan, tetapi laporan keuangan yang dilaporkan perusahaan tersebut akan menyesatkan investor karena tidak menggambarkan keadaan perusahaan yang sebenarnya. Dengan begitu akan memunculkan adanya asimetri informasi antara pihak agent maupun dari principal. Sehingga investor kurang tertarik maupun percaya untuk menanamkan modalnya yang mendorong munculnya perusahaan agency problem dikedua belah pihak.

Companies' Value and Tax 
Companies

Value and Tax

Avoidance

Dengan begitu jika semakin tinggi perusahaan melakukan tax avoidance maka dapat berdampak pada penurunan nilai perusahaan. Karena tingkat tax avoidance perusahaan dapat dilihat dari nilai Cash Effective Tax Ratio (CETR) perusahaan tersebut. Jika nilai Cash Effective Tax Ratio (CETR) itu lebih kecil atau dibawah dari tarif pajak 25\% sesuai peraturan pemerintah yang berlaku maka perusahaan tersebut terindikasi dengan tingkat agresivitas pajak yang tinggi sehingga berdampak pada penurunan nilai perusahaan (Ilmiani dan Sutrisno, 2014). Hasil penelitian ini sejalan dengan penelitian Ilmiani dan Sutrisno (2014), Wardani dan Juliani (2018) dan Fadillah (2018) yang menyatakan bahwa semakin tinggi tax avoidance yang dilakukan perusahaan maka semakin menurun nilai perusahaan yang tercermin dari harga saham perusahaan. Selain itu, dengan adanya praktik tax avoidance investor menganggap bahwa tindakan tax avoidance dianggap sebagai manipulasi data keuangan sehingga dapat menjadikan asimetri informasi dan terkena agency problem dimana akan berdampak pada penurunan nilai suatu perusahaan di mata investor. Hasil ini tidak sejalan dengan penelitian Victory dan Cheisviyani (2016), Kurniawan dan Syafruddin (2017) dan Apsari dan Setiawan (2018) yang menemukan pengaruh positif signifikan antara tax avoidance terhadap nilai perusahaan. Hasil penelitian ini menunjukkan bahwa tax avoidance yang tinggi menunjukkan nilai perusahaan yang baik sehingga investor akan merespon positif sinyal tersebut dan nilai perusahaan semakin meningkat.

\section{PENUTUP}

Berdasarkan hasil penelitian mengenai pengaruh tax avoidance terhadap nilai perusahaan. Objek dalam penelitian ini adalah perusahaan manufaktur yang terdaftar pada Bursa Efek Indonesia periode 2014 sampai 2018 dan diperoleh sampel sebanyak 125 pengamtan, maka dapat ditarik kesimpulan bahwa: Tindakan tax avoidance yang dilakukan perusahaan tidak mampu menjelaskan atau memberikan pengaruh terhadap nilai perusahaan, sedangkan dilihat dari hasil uji t atau parsial, tax avoidance memiliki nilai probabilitas sebesar 0,2682 dengan koefisien -0,719091. Berdasarkan hipotesis yang diajukan menerima Ho (menolak $\mathrm{H} a$ ) yang artinya secara statistik tax avoidance berpengaruh negatif dengan tingkat probabilitas lebih dari 5 persen terhadap nilai perusahaan (Y). Penelitian selanjutnya sebaiknya menambahkan variabel bebas lainnya yang mempengaruhi nilai perusahaan dan penelitian selanjutnya menggunakan periode waktu yang lebih panjang agar menambah jumlah data dan menghasilkan yang lebih baik.

\section{DAFTAR PUSTAKA}

Adityamurti, E. dan I. Ghozali. 2017. Pengaruh Penghindaran Pajak dan Biaya Agensi terhadap Nilai Perusahaan. Diponegoro Journal of Accounting 6(3): 1-12.

Agustianawati, P., \& Puspitasari, R. (2018). Stock Performance Analysis (Case Study PT ERATEX DJAJA, Tbk-ERTX). In THE INTERNATIONAL CONFERENCE ON ACCOUNTING AND MANAGEMENT SCIENCE (p. 107).

Basuki, A.T. dan Prawoto, N. 2017. Analisis Regresi. PT Raja Grafindo. Jakarta.

Budiman, J.S. 2012. Pengaruh Karakter Eksekutif terhadap Penghindaran Pajak (Tax Avoidance). Jurnal Ekonomika dan Bisnis, 3(12): 35-48.

Chen, X., N. Hu, X. Wang, dan X. Tang. 2013. Tax Avoidance and Firm Value: Evidence From China. Nankai Business Review International 5(1): 25-42.

Deriyarso, I. dan P. Prasetiono. 2014. Pengaruh Profitabilitas Terhadap Nilai Perusahaan dengan Corporate Social Responsibility Sebagai Variabel Moderating: Study Empiris pada Perusahaan Manufaktur yang Terdaftar di Bursa Efek Indonesia. Doctoral Dissertation. Fakultas Ekonomika dan Bisnis.

Fadillah, H. 2018. Pengaruh Tax Avoidance Terhadap Nilai Perusahaan dengan Kepemilikan Institusional Sebagai Variabel Moderasi. Jurnal Ilmiah Akuntansi Fakultas Ekonomi 4(1): 117-133. 
Ghozali, I. 2013. Aplikasi Analisis Multivariate dengan Program IMB SPSS 21 Update PLS Regresi. Edisi 7.Badan Penerbit Universitas Diponogoro. Semarang.

Gendalasari, G. G. (2020). Uji Kompetensi Di SMK Telekomedika Bogor. Jurnal Abdimas, 4(3), 211-220.

Gendalasari, G. G., \& Triandi, T. (2018, December). Strategy For Improving Performance and Competitive Advantages of Export-Based Shoe Msme in Bogor in The Free Trade Competition. In International Conference On Accounting And Management Science 2018 (pp. 315-321).

Hidayat, L., Muktiadji, N., \& Supriadi, Y. (2020, May). The Knowledge and Students' Interest to Investing in Investment Gallery. In 2nd International Seminar on Business, Economics, Social Science and Technology (ISBEST 2019)(pp. 142-145). Atlantis Press.

https://finance.detik.com/bursa-dan-valas/d-2962371/garuda-metalindo-bayar-utangrp-200-miliar-pakai-hasil-jual-saham diakses 20 November 2019

Ilmiani, A.dan C.R. Sutrisno. 2014. Pengaruh Tax Avoidance Terhadap Nilai Perusahaan Dengan Transparansi Perusahaan Sebagai Variabel Moderating. Jurnal Ekonomi Dan Bisnis 14(1): 30-39.

Kurniawan, A.F. dan Syafruddin, M. 2017. Pengaruh penghindaran pajak terhadap nilai perusahaan dengan variabel moderasi transparansi. Diponegoro Journal of Accounting 6(4): 94-103.

Manopo, H. dan F.V. Arie. 2016. Pengaruh Struktur Modal, Ukuran Perusahaan dan Profitabilitas Terhadap Nilai Perusahaan Otomotif yang Terdaftar Di Bursa Efek Indonesia Periode 2011-2014. Jurnal Riset Ekonomi, Manajemen, Bisnis Dan Akuntansi 4(2): 485-497.

Mardiasmo. 2018. Perpajakan. Andi Offset. Yogyakarta.

Merlina, M., \& Nuraini, A. (2020). Analisis Persepsi Dosen Akuntansi Dan Mahasiswa Akuntansi Mengenai Peranan Akuntan Di Era Revolusi Industri 4.0. JAS-PT (Jurnal Analisis Sistem Pendidikan Tinggi Indonesia), 4(2), 149-162.

Muhson, A. 2016. Pedoman praktikum analisis statistik. Fakultas Ekonomi Universitas Negeri Yogyakarta. Yogyakarta.

Munawar, A., \& Marpaung, B. S. (2013). Pengaruh Arus Kas Operasi Terhadap Peningkatan Kemampulabaan dan Pertumbuhan Perusahaan STUDI KASUS PADA PT. HOLCIM INDONESIA, TBK. Jurnal Ilmiah Manajemen Kesatuan, 1(3), 213-217.

Nuraini, A., Gendalasari, G. G., \& Sastra, H. (2017). Studi Peningkatan Pertumbuhan dan Nilai Perusahaan Sektor Perkebunan Melalui Analisis Kebijakan Dividend an Profitabilitas. Jurnal Ilmiah Manajemen Kesatuan, 5(2), 074-079.

Pamungkas, R., \& Puspitasari, R. (2018). Analisis Kebijakan Manajemen Keuangan jangka panjang (Studi kasus pada PT Ciputra Development Tbk). Jurnal Ilmiah Manajemen Kesatuan, 6(2), 81-87.

Setiawan, P.E. \& Apsari, L. 2018. Pengaruh tax avoidance terhadap nilai perusahaan dengan kebijakan dividen sebagai variabel moderasi. E-Jurnal Akuntansi Universitas Udayana 23(17): 65-1790.

Stella, L. A., \& Puspitasari, R. (2020, May). Analysis of Bank Rating with RGEC Method Case Study at PT Bank Mandiri (Persero) Tbk for the Period 2013-2017. In 2nd International Seminar on Business, Economics, Social Science and Technology (ISBEST 2019) (pp. 240-245). Atlantis Press.

Sudirjo, F. 2017. Evaluasi Penerapan Tax Planning untuk Upaya Meminimalkan Beban Pajak dalam Rangka Manajemen Pajak. Prosiding FEB UNTAG Semarang.

Supriadi, Y. (2020). Peningkatan Kapabilitas UMKM Binaan Rumah Kreatif Bogor Dalam Melakukan Analisa Laporan. Jurnal Abdimas, 4(1), 51-60.

Susilawati, N., \& Supriadi, Y. (2017). Pengaruh Cash Ratio dan Siklus Konversi Kas Terhadap Profitabilitas Perusahaan. Jurnal Ilmiah Manajemen Kesatuan, 5(2), 115124.

Companies' Value and Tax Avoidance Order 
Companies

Value and Tax

Avoidance
Undang-Undang Republik Indonesia Nomor 36 Tahun 2008 Pajak Penghasilan. 23 September 2008. Jakarta.

Utami, R. D., \& Nuraini, A. (2020). Pengaruh Penerapan Green Accounting dan Perputaran Total Aset Terhadap Profitabilitas. Jurnal Ilmiah Akuntansi Kesatuan, 8(2), 197-206.

Victory, G. dan C. Cheisviyani. 2016. Pengaruh Tax Avoidance Jangka Panjang Terhadap Nilai Perusahaan Dengan Kepemilikan Institusional Sebagai Variabel Pemoderasi (Studi Empiris Pada Perusahaan Manufaktur yang terdaftar di BEI periode 2010-2014). Jurnal WRA 4(1): 755-765.

Wardani, D.K. dan Juliani. 2018. Pengaruh Tax Avoidance Terhadap Nilai Perusahaan Dengan Corporate Governance Sebagai Variabel Pemoderasi. Jurnal Nominal 7(2): 47-61. https://doi.org/10.21831/nominal.v7i2.21349 